\title{
Pharmacognostical study of Desmodium caudatum
}

\author{
JUNNI LI, XIAOJING LIN, GENGQIU TANG, RONG LI, DONG WANG and SHENGGUO JI
}

\author{
School of Traditional Chinese Medicine, Guangdong Pharmaceutical University, 280, Outer \\ Ring Road East, Higher Education Mega Center, 510006 Guangdong, PR, China
}

Manuscript received on June 22, 2018; accepted for publication on October 1, 2018

\begin{abstract}
How to cite: LI J, LIN X, TANG G, LI R, WANG D AND JI S. 2019. Pharmacognostical study of Desmodium caudatum. An Acad Bras Cienc 91: e20180637. DOI 10.1590/0001-3765201920180637.
\end{abstract}

\begin{abstract}
Desmodium caudatum (Thunb.) DC, is an ever-green plant widely used in the central and southern China with great economic value for their medical values on fever, dysentery, gastroenteritis, rectal prolapse, snake bites, mastitis, and boils carbuncle. Despite its extensive uses as a traditional Chinese medicine, no systematic research on the identification of Desmodium caudatum has been reported. In this study, traditional pharmacognostical identification including the botanical origin and morphological characters, medicinal material characters, microscopic characters, physicochemical parameters determination and phytochemical screening, and DNA barcoding analysis were employed to establish an accurate and effective identification system of Desmodium caudatum. In addition, the molecular pharmacognosy study was adopted in order to identify the samples more accurately. The ITS loci of the nuclear genome and psbA-trnH loci of the chloroplast genome were selected and evaluated, which were the most variable loci. The study will be beneficial to the development of the quality standard and the identification of species.
\end{abstract}

Key words: Desmodium caudatum, DNA barcoding, quality standardization, traditional pharmacognostical identification.

\section{INTRODUCTION}

Traditional Chinese herbal medicine has been handed down for thousands of years in China. It is still widely used in the treatment of people's diseases and closely related to people's health. However, with the change of ecological environment and the variation of species, some characteristics of the medicinal plant from different origin are becoming more and more similar, which led to variety confusion and great quality differences of the Chinese herbal medicine in the market, and

Correspondence to: Shengguo Ji

E-mail: shengguo_ji@163.com

ORCid: https://orcid.org/0000-0002-5537-5825 there is a large hidden danger in medication safety. Therefore, it is extremely urgent to identify the varieties and guarantee quality of Chinese herbal medicines (Chan et al. 2015).

Desmodium caudatum (former name was Ohwia caudata (Thunb.) Ohashi) is a deciduous nitrogen-fixing plant distributed in China, India, Myanmar, Malaysia and Japan. Its root or whole plant was used as a traditional Chinese medicine to treat fever, gastroenteritis, dysentery, rheumatic arthritis. Modern pharmacological studies demonstrated that Desmodium caudatum had analgesic, anti-inflammatory (Ma et al. 2011), antioxidant (Li et al. 2013), anti-Alzheimer's disease (Guo et al. 2016), anti-MRSA (methicillin- 
resistant Staphylococcus aureus) (Sasaki et al. 2012a) and antifungal activities (Sasaki et al. 2012 b), and inhibitory activity against the filmforming growth of Zygosaccharomyces rouxii F51 (Sasaki et al. 2014).

To our best knowledge, no published work is available till date on the analysis and identification of Desmodium caudatum. Considering this, the present study was undertaken to study this plant. In the study, investigations were attempted to record morphological and microscopic characters of the plant material, physicochemical and phytochemical studies (chemical identification of different groups of compounds, and thin layer chromatography etc.), and genetic analysis using DNA barcodes. This would be meaningful in assessing the quality of the crude drug for further development.

\section{MATERIALS AND METHODS}

\section{COLLECTION AND AUTHENTICATION OF PLANT MATERIALS}

All the fresh materials including the root, stem, and leaf of the plant were collected from the Pharmaceutical Botanical Garden of Guangdong Pharmaceutical University, the physic garden of Guangzhou University of Chinese Medicine, South China Botanical Garden of Chinese Academy of Sciences, and the huolu-mountain of Guangzhou, China in September 2017, respectively. They were identified as Desmodium caudatum (Thunb.) DC of Leguminosae by Professor Shengguo Ji.

\section{TRADITIONAL PHARMACOGNOSY ANALYSIS}

The botanical origin and morphological characters of the plant such as type of leaf, shape, color, apex, margin, lamina, base venation and texture were analyzed and described by standard method (Amponsah et al. 2014).

For the microscopic characters, transverse sections of roots, stem and leaf were prepared by Henan Yulin education engineering co., Ltd.
(Duarte and Debur 2005). The roots and stems of the plants were cut into approximately $3 \mathrm{~cm}$ long segments, and the leaves including the main veins and both sides of them were cut into approximately $1 \mathrm{~cm}$ in width and 2 to $3 \mathrm{~cm}$ in length, which were soaked in FAA fixation solution and set aside. 2-3 fresh leaves were taken and directly torn to get the upper and lower leaf epidermis by using tweezers. The torn epidermis were placed in a petri dish containing distilled water, and a large one need to be divided into small pieces. Subsequently, the shape and stomatal axis, etc. of the upper and lower epidermis cells were observed, and the stomatal index was calculated by formula followed.

The stomatal index $=\frac{\text { the number of stomatal in the per unit area }}{\text { the number of stomatal in the per unit area }+ \text { the number of epidermic cells in the same unit area }} * 100 \%$

Appropriate amount of fresh plant materials were dried and shattered by pulverize crusher. The powder was screened with 65 mesh sieve and set aside. $0.1 \mathrm{~g}$ powder was taken out and sealed with 1-2 drops of dilute glycerol or distilled water, and then it was heated and permeabilized with saturated chloral hydrate solution to make slices. Afterwards, we can obtain some information about characteristics of the stone cell, calcium oxalate cluster crystal, resin channel fragment, nonglandular hair, ducts and starch grains, etc. via high resolution microscope Nikon ECLIPSE E100. The photograph was taken under visible light with the help of image processing application software Finial View.

The content of moisture content, total ash and acid-insoluble ash was calculated according to the edition of 2015 Chinese pharmacopoeia. In addition, $5 \mathrm{~g}$ powder of medicinal materials was extracted by ultrasonic extractor with $75 \%$ ethanol, ethyl acetate, acetone, methanol, trichloromethane, carbon tetrachloride, distilled water and petroleum ether for $1 \mathrm{~h}$, respectively. The filtrate was placed separately in the test tubes. Fluorescence color was observed at ultraviolet light and visible light (Kabra et al. 2018). 
For preliminary phytochemical screening (Khatoon et al. 2006), each of $3 \mathrm{~g}$ powdered material was extracted with water, petroleum ether, $75 \%$ ethanol and $0.5 \%$ hydrochloric acid solution by ultrasonic extractor for $30 \mathrm{~min}$, respectively. The extracts were used to observe the presence or absence of different phytoconstituents including triterpenoids, steroids, alkaloids, sugar, tannins, glycosides and flavanoids by usual prescribed chromogenic reaction. $1 \mathrm{~g}$ of medicinal powder was separately added into seven solvents viz. acetic acid, sulfuric acid, hydrochloric acid, nitric acid, ferric chloride, sodium hydroxide and potassium hydroxide. The sinking or floating behavior of powder and color change of solvent were observed and recorded.

Concerning thin-layer chromatography analysis, $2 \mathrm{~g}$ of medicine powder was extracted with $50 \mathrm{ml}$ ethanol by ultrasonic extraction for $30 \mathrm{~min}$. The filtrate was dried, and residue was dissolved with $1 \mathrm{ml}$ methanol to get the sample solution. $0.1 \mathrm{~g}$ of chlorogenic acid dissolved in $10 \mathrm{ml}$ methanol was used as the reference solution. The known quantity of sample solution and references solution were applied on the same silica gel $\mathrm{G}$ plate. The plate was eluted at room temperature $\left(21{ }^{\circ} \mathrm{C}\right)$ using a solvent system as chloroform/methanol (V/V, 7.5/2) with previously saturated twin trough chamber. The plate was observed at the wavelength $365 \mathrm{~nm}$ using the UV lamp. The photograph was taken under visible light with the help of image processing application software Finial View.

DNA ISOLATION, PCR AMPLIFICATION AND SEQUENCING PROCEDURES

Fresh leaf material was scrubbed with pure water and $75 \%$ ethanol successively. The treated leaf was put into the mortar sterilized at a high temperature, and then rapidly frozen and ground to powder by adding proper amount of liquid nitrogen. The total DNA was extracted by a novel rapid plant Genomic DNA extraction kit (batch number: B002006017) form Batek DP3111. The content of total DNA was determined by micro-ultraviolet-visible spectrophotometer. The purity of the extracted double-stranded DNA was evaluated by calculating the ratio of A260/A280. If the value is close to 1.8, it can be proved that the purity of the product is high enough. And the PCR can be carried out.

Polymerase chain reaction (PCR) was conducted using routine laboratory protocols (the primers are shown in Table I). The DNA fragments were amplified using the procedures followed: 94 ${ }^{\circ} \mathrm{C}, 5 \mathrm{~min}$ for DNA untwisting, 34 cycles at $94{ }^{\circ} \mathrm{C}, 30$ $\mathrm{s} ; 54{ }^{\circ} \mathrm{C}, 35 \mathrm{~s} ; 72{ }^{\circ} \mathrm{C}, 1 \mathrm{~min}$ for DNA amplification, and $72{ }^{\circ} \mathrm{C}, 10 \mathrm{~min}$ for DNA renaturation (Zou et al. 2011). PCR products were cleaned using PEG8000. The PCR amplification products of two sequences were electrophoresed by using $0.15 \%$ and $0.2 \%$ agarose gel. The one reason is to purify the amplified product, and the other is to determine the PCR success rate.

The DNA fragments were sequenced in Gene Denovo co., Ltd. The sequences were spliced and proofread using Chromas and DNMAN aimed to (1) remove the primer region and the low quality sequence according to the standard whether the base mass value (quality value) is greater than 10 , (2) splice the positive and negative sequences to obtain a complete gene sequence and (3) compare and proofread ITS and $p s b A-\operatorname{trn} H$ sequences of Desmodium caudatum with the sequence registered

TABLE I

The sequence of primer for PCR.

\begin{tabular}{ccc}
\hline & ITS & ps $\boldsymbol{b} \boldsymbol{A}$-trn $\boldsymbol{H}$ \\
\hline Primer forward & ITS4:TCCTCCGCTTATTGATATGC & p-Z2:GTTATGCATGAACGTAATGCTC \\
Primer reverse & ITS5:GGAAGTAAAAGTCGTAACAAGG & p-F2:CGCGCATGGTGGATTCACAATCC \\
\hline
\end{tabular}


in NCBI to confirm whether they have been reported.

\section{RESULTS}

THE BOTANICAL ORIGIN AND MORPHOLOGICAL CHARACTERS

Desmodium caudatum belongs to the Subgen. Catenaria (Benth.) Baker of genus Desmodium, family Leguminosae, and there is only one species in this subgenus, alias "qing jiu gang". It is an erect shrub or a subshrub with gray-brown bark. Desmodium caudatum has pinnate triple compound leaf which are flat and thick, with a deep sulcus on the upper surface. Its petiole is commonly 2-3.5 $\mathrm{cm}$ long, with extremely narrow wings on both sides, which is the most obvious characteristic distinguished from other different subgenera of genus Desmodium. Leaflet is leathery, pubescent on the both sides, and its margin is smooth.
Inflorescence rachis is densely pilose and mixed with small hooked hairs, with greenish-white corolla, measuring about $5 \mathrm{~mm}$ long. Pods are linear, flat, and wears hooked hairy (Upadhya et al. 2015, Vaghela et al. 2015). In general, its stem, branch, root, and leaf are used medicinally (Fig. 1).

\section{MEDICINAL MATERIAL CHARACTER IDENTIFICATION}

The medicinal material (shown in Fig. 2) is light and crisp, and the branches are grayish brown. Leaves are thin and papery, the intact of which is flattened to be lanceolate, with acuminate apex, cuneate base, smooth margin. The upper surface of the blade is green, and the bottom is gray. It is light weight, faint smell and slightly bitter taste.

\section{MICROSCOPIC CHARACTERS}

Transverse section of root (shown in Fig. 3) is somewhat circular in outline. The cork layer is

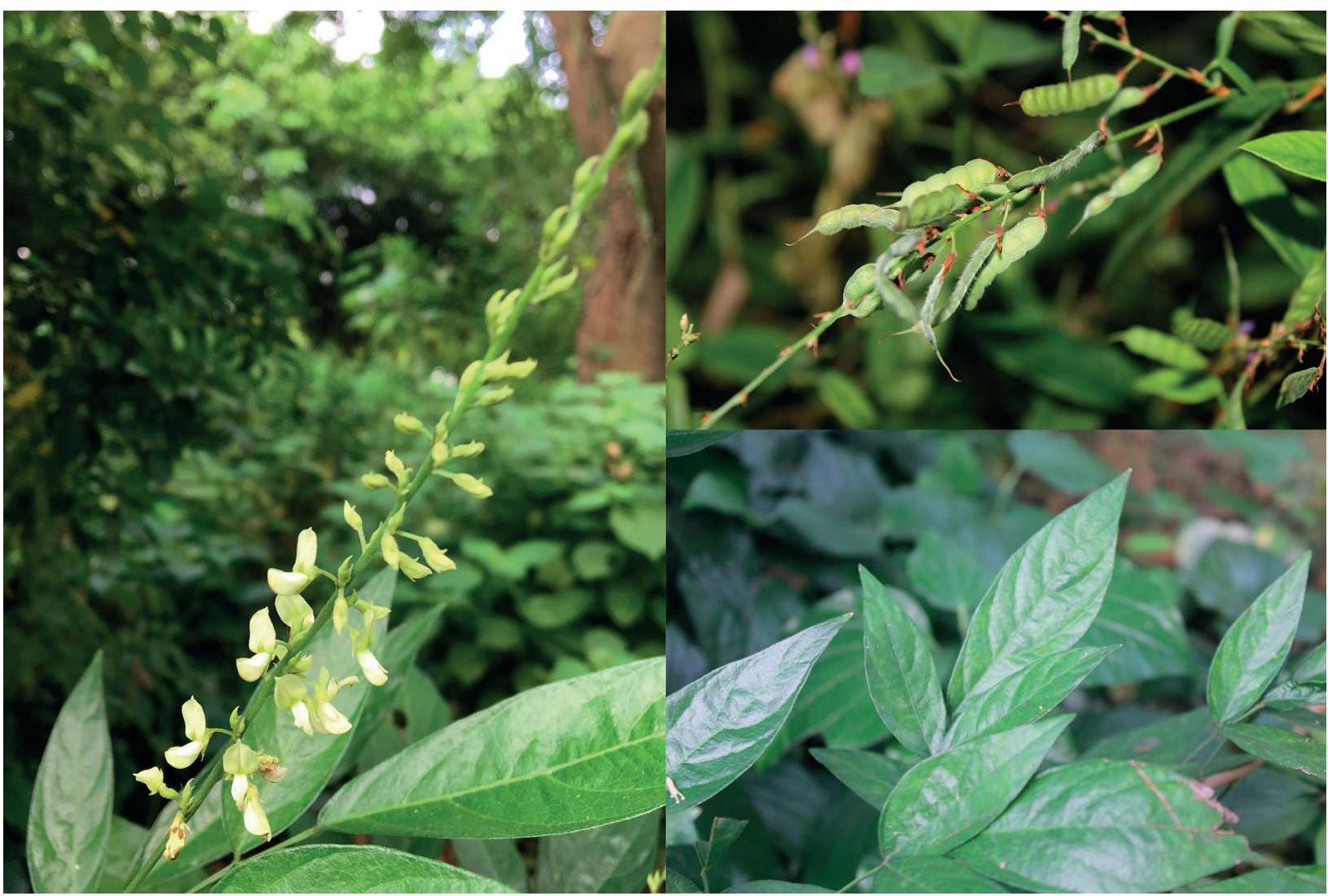

Figure 1 - The plant of Desmodium caudatum. 


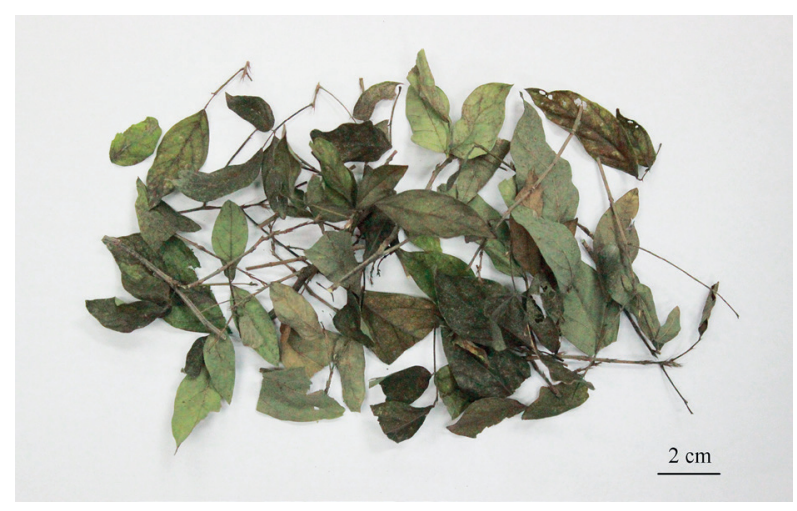

Figure 2 - The medicinal materials of Desmodium caudatum. Bars: $2 \mathrm{~cm}$.

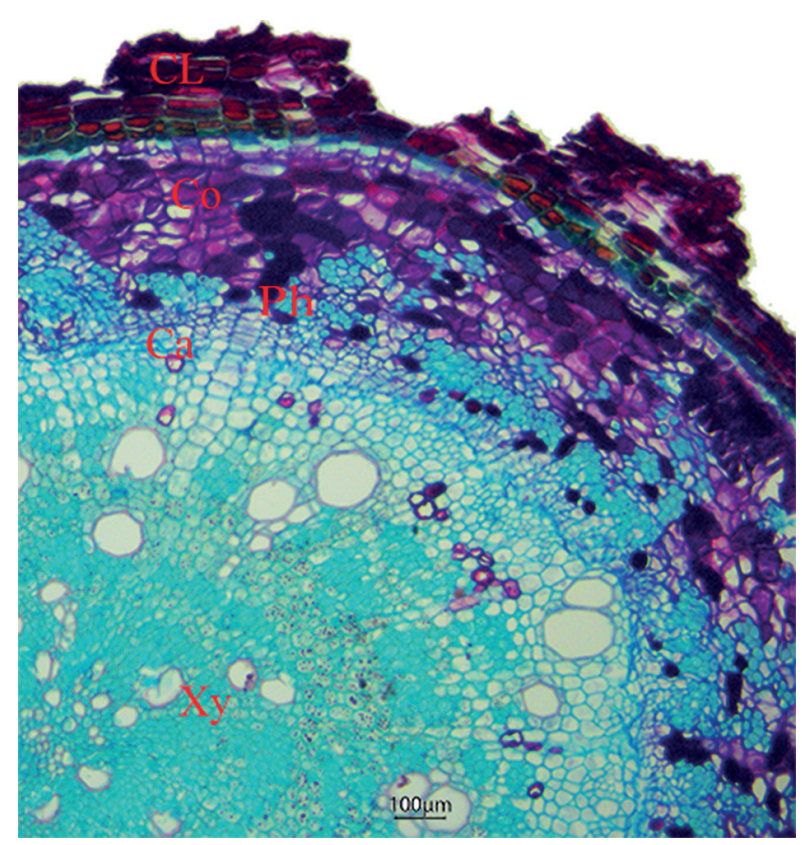

Figure 3 - Transverse section of root. CL: cork layer; Co: cortex; Ph: phloem; Ca: cambium; Xy: xylem. Bars: $100 \mu \mathrm{m}$.

thicker, slightly lignified, and the cells are closely arranged. The boundary between cortex and phloem is irregular and blurry. One or two layers of vascular cambium are present in between the xylem and phloem. The cambium layer is annular visibly. The xylem is broad, and the ducts are more scattered.

Transverse section of stem (shown in Fig. 4) is somewhat circular in outline and covered with thick cuticle followed by single layered, thin walled epidermal cells, and the nonglandular hair can be observed visibly. The cortex is slightly wider and the series of round cells are closely arranged. The phloem is narrow and cambium is annular. The xylem accounts for about $1 / 3$ of the transverse section, and the ducts are polygonal, slightly lignified and cybotactic. Pith is broad.

Transverse section of leaf vein (shown in Fig. 5 ) is wavy in the outline. Both side of the epidermis are composed of a row of cells arranged tangentially and closely. Beneath the epidermis of the main vein is a series of collenchyma cells. The palisade tissue is consisted of a layer of rectangular cells, while sponge tissue is loose. Main vein vascular bundle is shallowly sulciform, and pericycle fibre is clustered.

With leaf amphistomatic, the anticlinal walls of both the epidermis are wavy and stomata are paracytic type, and the stomatal indices are approximately $20.5 \%$ on abaxial surfaces. Glandular hairs are observed commonly (shown in Fig. S1 - Supplementary Material).

The powder was yellowish brown in color, with no distinct odor and a bitter taste. Microscopic powder features (Ankad et al. 2015) revealed the presence of crystals of calcium oxalate and round pollen grains with verrucous carvings and 3 germination holes. The epidermidis showed curlywalled polygonal epidermal cells. The crystal fiber was observed commonly and its diameter ranges from $4 \mu \mathrm{m}$ to $30 \mu \mathrm{m}$. Bordered pitted vessel and spiral vessels were observed occasionally. Glandular hairs were found to be unicellular on the top and 2-3 cells in the handle. And the nonglandular hairs were found to be short and crooked at the top, measuring about 55-102 um long (shown in Fig. S2).

\section{PHYSICOCHEMICAL PARAMETERS \\ DETERMINATION AND PHYTOCHEMICAL SCREENING}

The percentage of moisture content, total ash and acid-insoluble ash are tabulated in Table II. The 

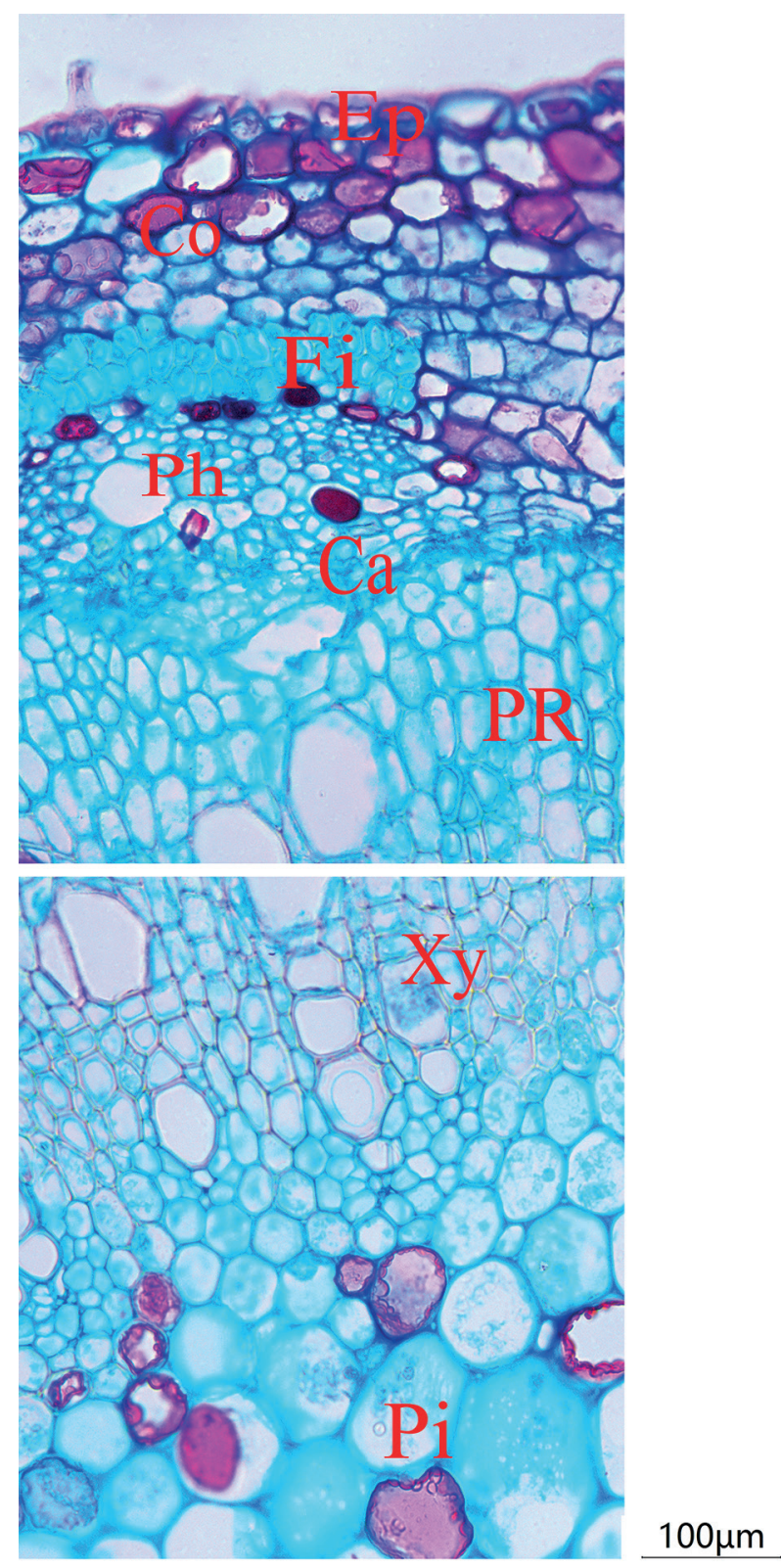

Figure 4 - Transverse section of stem. Ep: epidermides; Co: cortex; Fi: fibre; Ph: phloem; Ca: cambium; PR: pith ray; Xy: xylem; Pi: pith. Bars: $100 \mu \mathrm{m}$.

fluorescence characters of powdered drug impart a valuable role in the determination of quality and purity of the drug materials. The powdered drugs exhibited characteristic fluorescence when subjected to ultraviolet light and visible light. Fluorescence report of Desmodium caudatum powdered material is presented in Table III.
Presence and absence of different phytoconstituents were detected, and the specific results are shown in Tables IV, V and VI. There are different color reactions and behaviors when the powered material is put into different solvents, which is beneficial to rapid identification of drugs. The behavior study of the Desmodium caudatum powdered material in different solvents is recorded in Table VII.

\section{DEVELOPMENT OF TLC PROFILE OF ETHANOL EXTRACTS OF Desmodium caudatum}

Qualitative TLC of ethanol extract was carried out by using a solvent system as chloroform/methanol $(\mathrm{V} / \mathrm{V}, 7.5 / 2)$ to assure the presence of various phytochemicals. TLC chromatogram of ethanol extract showed a total of 4 spots at different $R f$ value $\left(\mathrm{Rf}_{\mathrm{a}}=0.225, \mathrm{Rf}_{\mathrm{b}}=0.291, \mathrm{Rf}_{\mathrm{c}}=0.491, \mathrm{Rf}_{\mathrm{d}}=0.600\right)$ at $365 \mathrm{~nm}$ (Ekayanti et al. 2017). Among which, the spot with $\mathrm{R}_{\mathrm{f}}=0.225$ is accordant with that of chlorogenic acid (shown in Fig. S3).

\section{DEVELOPMENT OF DNA BARCODING OF Desmodium caudatum}

DNA barcoding, still a relatively new technique, is well on its way to being accepted as a global standard for the purpose of species identification (Heinrich and Anagnostou 2017). Most of the potential barcode regions can be amplified and sequenced easily using the universal primers. However, ITS exhibited the highest sequence variability with the highest value of nucleotide diversity, its tiny variation sites information can be used for the study of genetic variation within species, while $p s b A$-trnH is more suitable for interspecific identification. The combination of ITS and $p s b A$-trnH is sufficient for identifying all the species and clusters in the genus. Therefore, the ITS loci and the $p s b A-t r n H$ loci were selected in the present study.

The whole ITS and $p s b A-t r n H$ fragment extraction was carried out for three times parallel, 
TABLE II

Physicochemical parameters of Desmodium caudatum.

\begin{tabular}{ccc}
\hline Physiochemical parameters & Results(\%) \\
\hline Ash value & Total ash & 9.56 \\
& Acid-insoluble ash & 2.94 \\
Moisture content & & 9.82 \\
\hline
\end{tabular}

TABLE III

Fluorescence characteristics of Desmodium caudatum.

\begin{tabular}{cccc}
\hline Reagent & Visible light & $\mathbf{2 5 4} \mathbf{~ n m ~ ( U V ~ l i g h t ) ~}$ & $\mathbf{3 6 6} \mathbf{~ n m}$ (UV light) \\
\hline $75 \%$ Ethanol & Green & Red & Dark red \\
Acetic ether & Green & Shiny red & Shiny red \\
Acetone & Invisible green & Shiny red & Shiny red \\
Methanol & Green & Red & Red \\
Trichlormethane & Yellowish-brown & Rose hermosa & Rose hermosa \\
Carbon tetrachloride & Yellow & Rose hermosa & Red \\
Distilled water & Brown & No fluorescence & No fluorescence \\
Petroleum ether & Yellow & Rose hermosa & Rose hermosa \\
\hline
\end{tabular}

TABLE IV

Preliminary phytochemical screening of water and petroleum ether extract from Desmodium caudatum.

\begin{tabular}{cccc}
\hline Chemical constituents & Reaction type & Reaction phenomenon & Positive or negative \\
\hline $\begin{array}{c}\text { Carbohydrates, } \\
\text { glycosides }\end{array}$ & Molish reaction & Purplish red in the interface & + \\
$\begin{array}{c}\text { Amino acids, peptides, } \\
\text { proteins }\end{array}$ & Triketohydrindene reaction & No obvious phenomenon & - \\
Saponins & Foam reaction & $\begin{array}{c}\text { Producing foam and lasting } \\
\text { for } 10 \text { min or more } \\
\text { Tannin }\end{array}$ & Ferric chloride reaction \\
Essential oils and fats & Filter paper test & Green, bluish green or dark purple & + \\
\hline
\end{tabular}

Positive reaction: +; Negative reaction: -.

TABLE V

Preliminary phytochemical screening of alcohol extract from Desmodium caudatum.

\begin{tabular}{cccc}
\hline Chemical constituents & Reaction type & Reaction phenomenon & Positive or negative \\
\hline Flavonoid & HCl-Mg reaction & Carnation & + \\
Flavonoid & Aluminium chloride reaction & Yellow fluorescence & + \\
Flavonoid & Ammonia fumigation reaction & Yellow fluorescence & + \\
Anthraquinones & Borntrager & Rufous & + \\
Phytosterol and & Acetic anhydride-Sulfuric acid & Color varied from yellow, red, & + \\
Triterpenoids & reaction & purple, cyan to green & - \\
Cardiac glycosides & Alkaline picric acid reaction & No obvious phenomenon & + \\
\hline
\end{tabular}

Positive reaction: +; Negative reaction: -. 


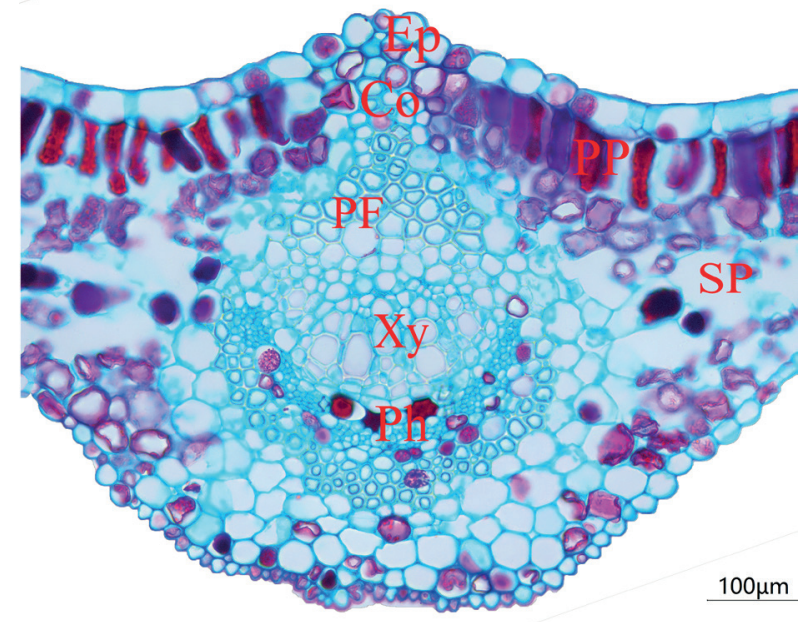

Figure 5 - Transverse section of leaf vein. Ep: epidermides; Co: collenchyma; PP: palisade parenchyma; $\mathrm{PF}$ : pericycle fibre; SP: spongy parenchyma; Xy: xylem; Ph: phloem. Bars: $100 \mu \mathrm{m}$.

and extraction success rate, PCR success rate and sequencing success rate were all $100 \%$. The sequencing results showed that the whole ITS sequence length was $711 \mathrm{bp}$, while $p s b A-t r n H$ sequence length was $430 \mathrm{bp}$. As for the percentage of base number, $\mathrm{A}$ is $29.4 \%, \mathrm{C}$ is $26.0 \%, \mathrm{G}$ is $20.5 \%$ and $\mathrm{T}$ is $24.1 \%$ for ITS sequence, and they are $41.9 \%, 12.1 \%, 11.4 \%$ and $34.7 \%$ for $p s b A-t r n H$ in proper order, respectively.

The sequence obtained in the study was compared with the same genus plants' sequences in NCBI (Li et al. 2012). The results demonstrated that the whole ITS fragment of Desmodium caudatum had not been reported in previous literature, and the login number that we have requested at Geenbank is MG991101.1. In addition, psbA-trnH sequence has been reported in 2017, and its login number was MF084278.1. Both of the two loci can be used as the DNA barcoding of Desmodium caudatum.

\section{DISCUSSION}

Desmodium caudatum is used extensively as an ancient traditional medicine for the treatment of wide range of diseases. In the present study, the whole plant was analyzed for its pharmacognostic features. Desmodium caudatum is an erect shrub or a subshrub having commonly $2-3.5 \mathrm{~cm}$ long petiole, with extremely narrow wings on both sides, which were important diagnostic characters. The Transverse section examination showed special features of its root, stem and leaf. The prominent diagnostic features of powder microscopy were calcium oxalate crystals, round pollen grains, curlywalled polygonal epidermal cells, crystal sheath fibers, bordered pitted vessel and spiral vessels, glandular hairs and non-glandular hairs, which can be considered as distinguishing characteristic for determining the anatomical structures and setting up the correct identity of this plant.

Physicochemical evaluations provide various important parameters like moisture content, total ash and acid-insoluble ash content. The ash values determined in the present study may be useful in stabilizing standards of purity and quality. The fluorescence study showed characteristic fluorescence under visible light and UV light, and this may be useful for the detection of adulterants. Preliminary phytochemical screening was done to check the presence of active constituents. It reveals the presence of carbohydrates, glycosides, saponins, tannin, essential oils and fats, flavonoid, anthraquinones, phytosterol and triterpenoids, cardiac glycosides and alkaloids. The behavior study of power is beneficial to rapid identification of drugs, and the phenomenon is obvious.

The TLC chromatogram of extracts may be useful for the confirmation of presence of some constituents along with the respective $\mathrm{Rf}$ value. The results showed the band with $\mathrm{Rf}$ value 0.225 was attributed to chlorogenic acid for Desmodium caudatum. There was no concrete compound found to be in accordance with the other three points, but the three points could also be used as a diagnostic feature.

Recently, various techniques are in use, or have been tried for species identification. Traditional pharmacognostical identification and thin-layer 
TABLE VI

Preliminary phytochemical screening of hydrochloric acid solution extract from Desmodium caudatum.

\begin{tabular}{cccc}
\hline Chemical constituents & Reaction type & Reaction phenomenon & Positive or negative \\
\hline & Potassium bismuth iodide reaction & No obvious phenomenon & - \\
& Iodine-potassium iodide reaction & Brown precipitation & + \\
Alkaloids & Phosphomolybdic acid reaction & White precipitation & + \\
& Silicotungstic acid reaction & White precipitation & + \\
\hline
\end{tabular}

Positive reaction: +; Negative reaction: -.

TABLE VII

The behavior study of powder of Desmodium caudatum.

\begin{tabular}{cccccccc}
\hline Reagent & $\begin{array}{c}\text { Glacial acetic } \\
\text { acid }\end{array}$ & Sulphuric acid & $\begin{array}{c}\text { Potassium } \\
\text { hydrate }\end{array}$ & $\begin{array}{c}\text { Sodium } \\
\text { hydrate }\end{array}$ & $\begin{array}{c}\text { Ferric } \\
\text { perchloride }\end{array}$ & $\begin{array}{c}\text { Hydrogen } \\
\text { nitrate }\end{array}$ & $\begin{array}{c}\text { Hydrochloric } \\
\text { acid }\end{array}$ \\
\hline $\begin{array}{c}\text { The color of } \\
\text { solution }\end{array}$ & Olivine & Brown & Yellowish & Yellowish & Olivine & Red & Green \\
$\begin{array}{c}\text { The behavior of } \\
\text { powder }\end{array}$ & Precipitate & Carbonization & Floatage & Floatage & Floatage & Floatage & Floatage \\
\hline
\end{tabular}

chromatography identification, as conventional means of detection, were helpful to preliminary study on medicinal materials. Nevertheless, the methods have some limitations in the identification of the medicinal materials because of its strong subjectivity or lack of singleness. And now one of the most important techniques is DNA barcoding, which has uniqueness.

The technology of DNA barcoding was used to sequence a representative, sufficiently variant, easily amplified, and relatively short region of DNA for species identification, taxonomy and conservation. The CBOL Plant Working Group recommend the 2-locus combination of $\mathrm{rbcL}+$ matK as the land plants barcode by comparing and assessing the recoverability, sequence quality, and levels of species discrimination of 7 leading candidate plastid DNA regions (atpF-atpH spacer, matK gene, rbcL gene, rpoB gene, rpoC1 gene, psbK-psbI spacer, and trnH-psbA spacer) from 907 samples of 550 species in 2009 (CBOL Plant Working Group 2009), to be supplemented with additional markers such as plastid trnH-psbA and nuclear ribosomal internal transcribed spacer (ITS). And in 2011(China Plant BOL Group et al. 2011), China Plant BOL Group assessed the effectiveness and universality of these four barcode markers in seed plants by using 6,286 individuals representing 1,757 species in 141 genera of 75 families (42 orders). The results demonstrated ITS had highest discriminatory power of the four markers, and a combination of ITS and any plastid DNA marker was able to discriminate $69.9-79.1 \%$ of species, compared with $r b c L+m a t K$ for only $49.7 \%$. However, it is difficult to amplify and directly sequence ITS in its entirety, while ITS2 is a useful backup because it is easier to amplify and sequence. Therefore, they proposed that ITS/ITS2 should be incorporated into the core barcode for seed plants.

The quality of a particular herbal medicine depends not only on the species, but also on the provenance of such species and medicinal parts. With the advent of DNA barcoding, the identification of the genuine medicinal plants of high quality, with known provenance, is more likely to be achieved (Chen et al. 2013, Song et al. 2015, Reunov et al. 2018). Finally, the expensive imitations with inferior medicinal properties could be eliminated from the herbal medicine markets. However, the techniques used so far have suffered from low efficiency, low reproducibility and 
low reliability. Species identification based on DNA barcoding is a method of high efficiency, reproducibility and reliability, but might show low resolution. And a great deal of effort is still needed before DNA barcoding of plants can be considered sufficiently reliable for widespread practical application. Above all, a consensus on the strategy for barcode development should be reached as soon as possible.

In addition, Ahmad et al. have designed to bring out the relationships among different available accessions and study biodiversity conservation through simple sequence repeat (SSR) and inter transcribed spacer (ITS) markers of Desmodium gangeticum (L.) DL. Finally they found that SSR and ITS markers can be used for the population conservation and genetic diversity analysis of Desmodium gangeticum, and could also be a good example for other medicinally important plants (Ahmad et al. 2016).

In general, information generated in this work may be useful to further development of Desmodium caudatum, which may act as the reference information and produce a solid basis for proper identification, authentication, collection and investigation of the plant material.

\section{CONCLUSION}

In the present study, Desmodium caudatum was identified systematically based on traditional pharmacognostical, thin-layer chromatography and DNA barcoding analysis, which is beneficial to the development of the quality standard and the identification of species. Our study provides information for the fundamental understanding of Desmodium caudatum and is therefore the basis for further experiments. And the research method is of significance to enhance the standardization of quality standard of Chinese medicinal materials (Pandavadra and Chanda 2014), to establish modern information system of traditional Chinese medicine and to ensure the production of high quality Chinese medicinal materials.

\section{ACKNOWLEDGMENTS}

We are most grateful to Dr. Tao Guo from Henan University of Chinese Medicine and Dr. Dong Dong from Jinan University for reviewing and editing the manuscript, as well as valuable advice.

\section{AUTHOR CONTRIBUTIONS}

Shengguo Ji conceived and designed the study. Xiaojing Lin provided the data. Junni Li wrote the manuscript. Dong Wang, Genqiu Tang, and Rong Li reviewed and edited the manuscript. All authors read and approved the manuscript.

\section{REFERENCES}

AHMAD HRF, TIWARI S, GANDHI SG, KUMAR A, BRINDAVANAM NB AND VERMA V. 2016. Genetic Diversity Analysis among Accessions of Desmodium gangeticum (L.) DL with Simple Sequence Repeat (SSR) and Internal Transcribed Spacer (ITS) Regions for Species Conservation. J Biodivers Biopros 3: 2.

AMPONSAH IK, MENSAH AY, OTOO A, MENSAH MLK AND JONATHAN J. 2014. Pharmacognostic standardisation of Hilleria latifolia (Lam.) H. Walt. (Phytolaccaceae). Asian Pac J Trop Biomed 4(12): 941946.

ANKAD GM, KONAKERI RT, HEGDE HV AND ROY S. 2015. Variation in Pharmacognostic Characters and Polyphenolic Contents among Four Species of Medicinal Plants from the Genus Spermacoce (Rubiaceae). Indian J Pharm Sci 77(4): 446-452.

CBOL PLANT WORKING GROUP. 2009. A DNA barcode for land plants. Proc Natl Acad Sci USA 106(31): $12794-$ 12797.

CHAN K, ZHANG H AND LIN Z. 2015. An overview on adverse drug reactions to traditional Chinese medicines. Brit J Clin Pharmaco 80(4): 834-843.

CHEN X, LIAO B, SONG J, PANG X, HAN J AND CHEN S. 2013. A fast SNP identification and analysis of intraspecific variation in the medicinal Panax species based on DNA barcoding. Gene 530(1): 39-43.

CHINA PLANT BOL GROUP ET AL. 2011. Comparative analysis of a large dataset indicates that internal transcribed spacer (ITS) should be incorporated into the core barcode 
for seed plants. Proc Natl Acad Sci USA 108(49): 1964119646.

DUARTE MR AND DEBUR MC. 2005. Stem and leaf morphoanatomy of Maytenus ilicifolia. Fitoterapia 76(1): 41-49.

EKAYANTI M, ARDIANA L, NAJIB SZ, SAURIASARI R AND ELYA B. 2017. Pharmacognostic and Phytochemical Standardization of White Tea Leaf (Camellia sinensis L. Kuntze) Ethanolic Extracts. Pharmacogn J 9(2): 221-226.

GUO J, FENG X, ZHOU S, YAN WX AND MENG D. 2016. Potential anti-Alzheimer's disease activities of the roots of Desmodium caudatum. Ind Crop Prod 90: 94-99.

HEINRICH M AND ANAGNOSTOU S. 2017. From Pharmacognosia to DNA-Based Medicinal Plant Authentication - Pharmacognosy through the Centuries. Planta Med 83(14/15): 1110-1116.

KABRA A, SHARMA R, SINGLA S, KABRA R AND BAGHEL US. 2018. Pharmacognostic characterization of Myrica esculenta leaves. J-AIM. Available at: https://doi. org/10.1016/j.jaim.2017.07.012.

KHATOON S, RAI V, RAWAT AK AND MEHROTRA S. 2006. Comparative pharmacognostic studies of three Phyllanthus species. J Ethnopharmacol 104(1-2): 79-86.

LI M, WONG KL, CHAN WH, LI JX, BUT PP, CAO H AND SHAW PC. 2012. Establishment of DNA barcodes for the identification of the botanical sources of the Chinese 'cooling' beverage. Food Control 25: 758-766.

LI W, SUN YN, YAN XT, YANG SY, KIM S, CHAE D, HYUN JW, KANG HK, KOH YS AND KIM YH. 2013. Anti-inflammatory and antioxidant activities of phenolic compounds from Desmodium caudatum leaves and stems. Arch Pharmacal Res 37(6): 721-727.

MA KJ, ZHU ZZ, YU CH, ZHANG H, LIU J AND QIN LP. 2011. Analgesic, anti-inflammatory, and antipyretic activities of the ethanol extract from Desmodium caudatum. Pharm Biol 49(4): 403-407.

MA X, ZHENG C, HU C, RAHMAN K AND QIN LP. 2011. The genus Desmodium (Fabaceae)-traditional uses in Chinese medicine, phytochemistry and pharmacology. J Ethnopharmacol 138(2): 314-332.

PANDAVADRA M AND CHANDA S. 2014. Development of quality control parameters for the standardization of Limonia acidissima L. leaf and stem. Asian Pac J Trop Med 7S1: S244.

REUNOV A, REUNOVA G, ATOPKIN D, REUNOVA Y, MUZAROK T, ZAKHAROV E AND ZHURAVLEV Y.
2018. The Identification of Araliaceae Species by ITS2 Genetic Barcoding and Pollen Morphology. Planta Med 84(01): 42-48.

SASAKI H, KASHIWADA Y, SHIBATA H AND TAKAISHI Y. 2012a. Prenylated flavonoids from Desmodium caudatum, and evaluation of their anti-MRSA activity. Phytochemistry 82(1): 136-142.

SASAKI H, KASHIWADA Y, SHIBATA H AND TAKAISHI Y. 2012b. Prenylated flavonoids from the roots of Desmodium caudatum and evaluation of their antifungal activity. Planta Med 78(17): 1851-1856.

SASAKI H, SHIBATA H, IMABAYASHI K, TAKAISHI Y AND KASHIWADA Y. 2014. Prenylated Flavonoids from the Stems and Leaves of Desmodium caudatum and Evaluation of Their Inhibitory Activity against the FilmForming Growth of Zygosaccharomyces rouxii F51. J Agr Food Chem 62(27): 6345-6353.

SONG X, LI Y, XU G, LIU C, LIU Y, ZHANG X, LIU Y, LIU S AND GU X. 2015. Identification of Notoginseng powder based on similarity to "DNA Barcoding Core-genotype". Mitochondr DNA 28(3): 1.

UPADHYA V, ANKAD GM, PAI SR, HEGDE SV AND HEGDE HV. 2015. Preliminary pharmacognostic screening of Achyranthes coynei stem. J-AIM 6(2): 134138.

VAGHELA BD, PATEL BR AND PANDYA PN. 2015. A comparative pharmacognostical profle of Desmodium gangeticum DC. and Desmodium laxiflorum DC. AYU 33(4): 552-556.

ZUO Y, CHEN Z, KONDO K, FUNAMOTO T, WEN J AND ZHOU S. 2011. DNA barcoding of Panax species. Planta Med 77(2): 182-187.

\section{SUPPLEMENTARY MATERIAL}

Figure S1 - Micrograph of leaf epidermis of Desmodium caudatum, A represents the upper epidermis, whereas B is the lower epidermis. Bars: $\mathrm{A}=50 \mu \mathrm{m}, \mathrm{B}=30 \mu \mathrm{m}$.

Figure S2 - Microscopic powder features of Desmodium caudatum. PC: parenchyma cell; Fi: fibre; SV: spiral vessels; PV: pitted vessel; GH: glandular hairs; NGH: nonglandular hair; SC: solitary crystal; PG: pollen grain. Bars: $50 \mu \mathrm{m}$.

Figure S3 - TLC chromatogram of Desmodium caudatum. (1, 2, 3: Sample solution; 4: the Reference solution). 